\title{
Retinal Neurovascular Coupling in Diabetes
}

\author{
Gerhard Garhöfer ${ }^{1}$, Jacqueline Chua ${ }^{2,3,4}$, Bingyao Tan ${ }^{2,4}$, Damon Wong ${ }^{2,4}$, Doreen Schmidl ${ }^{1}$ \\ and Leopold Schmetterer 1,2,3,4,5,6,7,* \\ 1 Department of Clinical Pharmacology, Medical University Vienna, 1090 Vienna, Austria; \\ gerhard.garhoefer@meduniwien.ac.at (G.G.); doreen.schmidl@meduniwien.ac.at (D.S.) \\ 2 Singapore Eye Research Institute, Singapore National Eye Centre, Singapore 169856, Singapore; \\ jacqueline.chua.y.m@seri.com.sg (J.C.); bingyao.tan@ntu.edu.sg (B.T.); damon.wong@ntu.edu.sg (D.W.) \\ 3 Academic Clinical Program, Duke-NUS Medical School, Singapore 169857, Singapore \\ 4 SERI-NTU Advanced Ocular Engineering (STANCE), Singapore 639798, Singapore \\ 5 Institute for Health Technologies, Nanyang Technological University, Singapore 308232, Singapore \\ 6 Center for Medical Physics and Biomedical Engineering, Medical University Vienna, 1090 Vienna, Austria \\ 7 Institute of Molecular and Clinical Ophthalmology, CH-4031 Basel, Switzerland \\ * Correspondence: leopold.schmetterer@meduniwien.ac.at; Tel.: +43-1-40400-29810
}

Received: 27 July 2020; Accepted: 27 August 2020; Published: 1 September 2020

\begin{abstract}
Neurovascular coupling, also termed functional hyperemia, is one of the physiological key mechanisms to adjust blood flow in a neural tissue in response to functional activity. In the retina, increased neural activity, such as that induced by visual stimulation, leads to the dilatation of retinal arterioles, which is accompanied by an immediate increase in retinal and optic nerve head blood flow. According to the current scientific view, functional hyperemia ensures the adequate supply of nutrients and metabolites in response to the increased metabolic demand of the neural tissue. Although the molecular mechanisms behind neurovascular coupling are not yet fully elucidated, there is compelling evidence that this regulation is impaired in a wide variety of neurodegenerative and vascular diseases. In particular, it has been shown that the breakdown of the functional hyperemic response is an early event in patients with diabetes. There is compelling evidence that alterations in neurovascular coupling precede visible signs of diabetic retinopathy. Based on these observations, it has been hypothesized that a breakdown of functional hyperemia may contribute to the retinal complications of diabetes such as diabetic retinopathy or macular edema. The present review summarizes the current evidence of impaired neurovascular coupling in patients with diabetes. In this context, the molecular mechanisms of functional hyperemia in health and disease will be covered. Finally, we will also discuss how neurovascular coupling may in future be used to monitor disease progression or risk stratification.
\end{abstract}

Keywords: neurovascular coupling; diabetes; retina; ocular blood flow regulation; functional hyperemia

\section{Introduction}

Diabetes is a complex systemic disease, frequently accompanied by serious long-term microvascular and macrovascular complications [1]. These complications affect a wide variety of different organs in the human body, including the eye. As such, diabetic eye diseases-more importantly diabetic retinopathy and diabetic macula edema-are among the most sight-threatening ocular pathologies worldwide, and their prevalence is expected to considerably increase in the near future $[2,3]$.

Although the pathogenesis of diabetic retinopathy has not yet been fully elucidated [4], there is compelling evidence that vascular changes, ocular perfusion disturbances as well as tissue hypoxia 
play a major role in its pathogenesis [5,6]. Impaired blood flow may cause under- or overperfusion, which in turn triggers microvascular complications [7]. Blood flow in the eye cannot be considered to be static but is dynamically regulated in response to various stimuli [8]. More specifically, as discussed in detail below, ocular blood flow is adapted in response to exogenous factors such as changes in ocular perfusion pressure [9] (usually referred to as pressure autoregulation) or to metabolic stimuli such as hypoxia or hyperoxia $[10,11]$. In addition, tissues with high neural activity such as the retina show an intrinsic mechanism to adapt blood flow to increased metabolic demands caused by firing neurons. This regulatory response, which is called functional hyperemia or neurovascular coupling, is a key element that ensures the supply of the retinal tissue with oxygen and other nutrients to changing local metabolic requirements due to changing neural activity [12]. As discussed in detail below, an intact neurovascular coupling mechanism is highly dependent on a complex interaction between neurons and blood vessels to meet the metabolic demand that arises from increased neural activation. Malfunction of neurovascular coupling may lead to transient hypoperfusion and trigger other detrimental consequences such as local hypoxia and cellular damage [13,14].

The current review focuses on retinal functional hyperemia in patients with diabetes. We will discuss the role of neurovascular coupling as an intrinsic mechanism to adapt perfusion to changes in metabolic demand and how an impairment of this regulation process may contribute to the pathogenesis of diabetic complications in the eye. Further, we will describe how neurovascular coupling may in the future be used to monitor disease progression or risk stratification.

\section{Ocular Vasculature and Diabetes}

The human eye is the only organ in the human body where direct and non-invasive visualization of the microcirculation is possible. Briefly, the posterior part of the eye receives its blood supply through two different and independent vascular beds: the retinal circulation, which nourishes the inner part of the retina, and the choroid, supplying the outer part of the retina including the photoreceptors. The central retinal artery enters the eye with the optic nerve head and then branches into an upper and lower part, which in turn divides into a temporal and nasal vessel branch. When entering the optic nerve head, the central retinal artery has a diameter of approximately $170 \mu \mathrm{m}$ [15]. Whereas fundus-camera-based systems allow for the measurements of vessel calibers down to approximately $60 \mu \mathrm{m}$, which corresponds to the caliber of peripheral branch arteries, more sophisticated techniques allow for visualization of retinal vessels down to the capillary level [16]. Thus, researchers were interested for decades in identifying microvascular changes at the level of the retina and in determining whether they can provide information regarding systemic cardiovascular diseases such as arterial hypertension, arteriosclerosis, or stroke [17-19].

It has been speculated that changes in retinal vessel calibers may serve as biomarkers for the prediction of cardiovascular events such as myocardial infarction or stroke and allow for the early identification of high-risk patients [20].

In diabetes, microvascular complications, where retinal neovascularization or microvascular lesions are predominantly seen, it does not come as a surprise that the role of ocular blood flow and its regulation has gained considerable interest. Indeed, it is generally accepted now that retinal vessels are early and common targets of diabetic damage and might serve as biomarkers for diabetes-related microvascular complications [21].

Starting in the 1990s, computer-assisted analysis methods for precise in vivo assessment of retinal vessel calibers based on digitized fundus photographs became available allowing for the non-invasive quantification of retinal vessel diameter changes in large-scale studies [22,23]. More recent fundus-camera-based systems extend this approach and allow for the automatic assessment of several more complex vessel-related measures such as the arterio-venous ratio (Figure 1). 


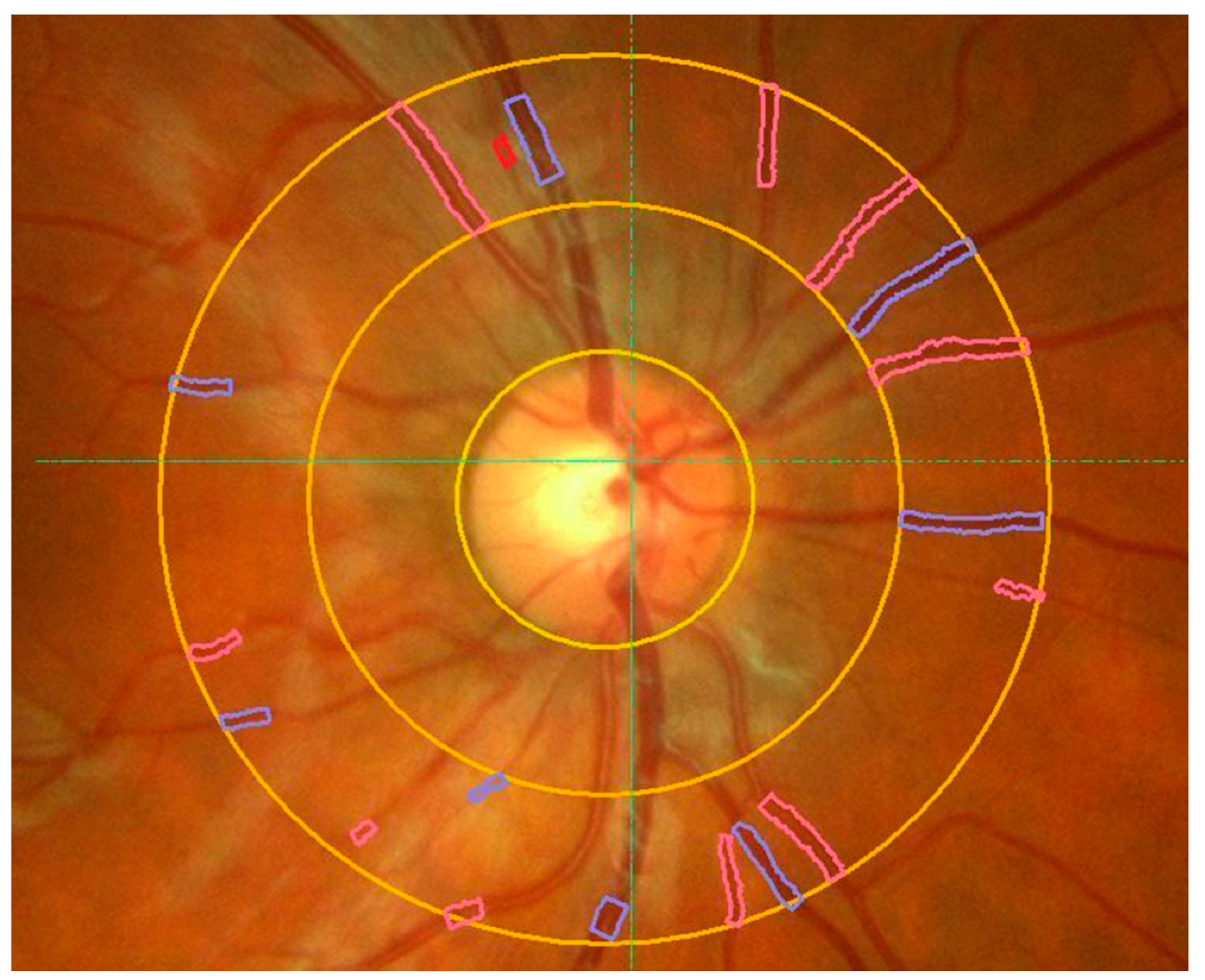

Figure 1. Automatic assessment of retinal vessel diameters using a commercially available retinal vessel analyzer. Retinal vessels enter the eye via the optic nerve head $(\mathrm{ONH})$ and then divide into branches (see text for details). Vessel calibers of retinal arteries (red) and retinal veins (blue) are automatically detected by the software. Yellow circles indicate the $\mathrm{ONH}$ and one and two disc diameter distances from the $\mathrm{ONH}$. The arterio-venous ratio $(\mathrm{A}-\mathrm{V})$ ratio is calculated automatically by the software.

Using this approach, a variety of epidemiological studies have investigated alterations in retinal vessel diameters in patients with diabetes and their potential use as a biomarker for the progression of the disease. The studies, however, produced mixed results. Prospective data from two large epidemiological studies, the Atherosclerosis Risk in Communities (ARIC) Study and Beaver Dam Eye Study, showed that non-diabetic individuals with a smaller arterio-venous ratio, a measure based on the ratio of total retinal arterial diameter to that of retinal veins, had a considerably higher risk of incident diabetes [24,25]. A comparable result was found in the Australian Diabetes, Obesity, and Lifestyle Study, which reported that retinal arteriolar narrowing predicts the incidence of diabetes [26].

In contrast to these findings, other studies found increased retinal vessel calibers [27] or failed to identify a clear association between vessel calibers and incident diabetes $[28,29]$. The reason for these differing results is unclear but may be at least partially related to differences in the methodology used for vessel caliber measurement. Most of the large epidemiological studies have used the ratio between retinal arterial and venous diameters to assess changes in retinal vasculature independent from the individual angio-architecture and the refraction of the eye [23]. This method largely relies on the assumption that venous vessel diameters are not affected by the disease. This might, however, not necessarily be the case: The authors of the Rotterdam Eye Study state that the changes in arterio-venous ratio as observed in some of the studies may be attributed rather to venous dilatation than to arteriolar constriction as previously hypothesized [29]. The latter interpretation is also strengthened by a recent meta-analysis including data of more than 18,000 individuals, which reports that wider retinal venules but not narrower retinal arterioles are associated with an increased risk for diabetes [30].

In addition to the disease per se, vessel calibers may be sensitive to changes in glucose concentrations, which further complicates the interpretation of the results [31]. For a more in-depth 
description and discussion regarding retinal vessel diameters as a potential biomarker for diabetes, the reader is referred to review articles published previously $[21,32,33]$.

\section{Microvascular Changes in Patients with Diabetes}

It is well established that microvascular changes are an early event in the disease process [1]. Among these, microaneurysms are the earliest detectible alterations in diabetic retinopathy [34]. Clinically, microaneurysms can be identified by ophthalmoscopy as deep-red dots varying from 25 to $100 \mu \mathrm{m}$ in diameter. There is general agreement that the presence and number of microaneurysms have strong predictive value with respect to progression of diabetic retinopathy [35]. Further anatomical alterations such as thickening of the vascular basement membrane and pericyte loss are also well described as early pathological features in patients with diabetes [7]. Recent technical advances in ocular imaging techniques, most importantly the introduction of optical coherence tomography angiography (OCT-A), allow for the non-invasive visualization and quantification of retinal microvascular changes [36]. OCT-A provides depth-resolved images of the retinal and choroidal vasculature approaching almost histological resolution, which has considerably increased our understanding of microvascular alterations in patients with diabetes [37]. Furthermore, OCT-A allows for the quantification of vascular density in different layers of the retinal vascular tissue and might, therefore, be a suitable tool to monitor disease progression. Using this technology, it has been shown that patients with diabetes exhibit an increase in the foveal avascular zone [38-40] most probably due to capillary loss and/or a decrease of parafoveal blood flow (Figure 2). In addition, it is reported that retinal vessel density as measured using OCT-A is reduced in patients with diabetes depending on the severity of the retinopathy [41-46]. The reader is referred to a recent review article for a more in-depth discussion regarding the OCT-A findings in persons with diabetes [47].

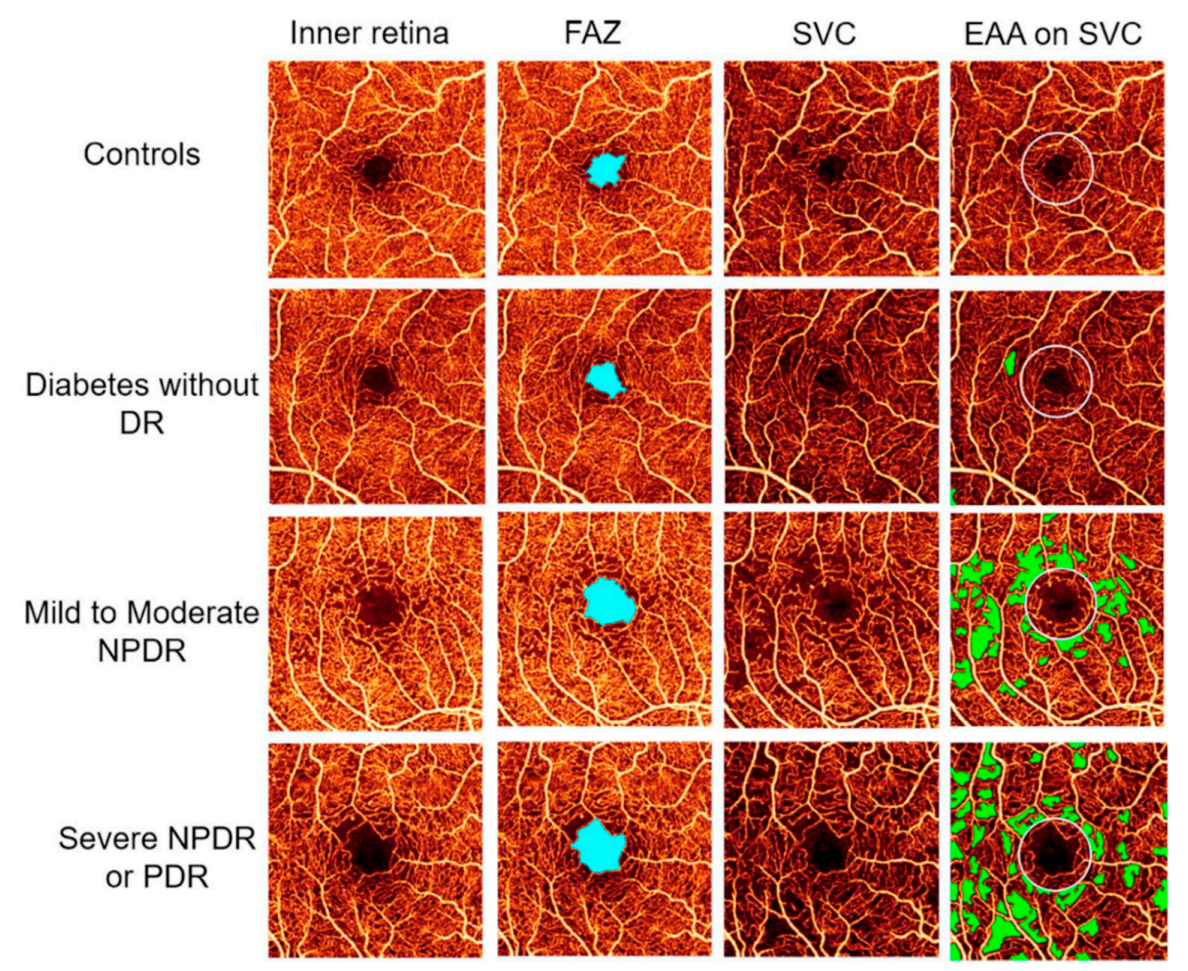

Figure 2. Optical coherence tomography angiography of the inner central retina in healthy subjects and in patients with diabetic retinopathy of different severities (first column). Second column shows the foveal avascular zone (FAZ, light blue), third column the superficial vascular layer (SVC), and the fourth column the extrafoveal avascular area (EAA, green) on the SVC. From [45] with permission. 


\section{Diabetes and Blood Flow}

Although the above-mentioned results indicate that patients with diabetes have altered ocular perfusion, diameter measurements alone are insufficient to draw conclusions on volumetric blood flow. To investigate whether ocular perfusion is compromised in patients with diabetes, more sophisticated measurement techniques, which allow for the assessment for blood flow, are necessary. However, currently no gold standard for the measurement of retinal blood flow exists and the available methods are technically demanding or suffer from limitations that limit their use in patients with ocular diseases [48,49].

The current evidence regarding blood flow changes in patients with diabetes is sparse and sometimes contradicting. Although most of the studies found changes in the blood flow in patients with diabetes, there is still no consensus regarding the pattern of blood flow changes with respect to different types of diabetes or the clinical severity of the disease. More specifically, both reduced [50-52] and increased blood flow [53-56] have been reported in the retina of diabetic patients, depending on the type of diabetes and the method used for blood flow measurement.

As stated above, a wide variety of methods have been used to study retinal blood flow, and the techniques suffer from methodological problems, including poor reproducibility [48]. Doppler optical coherence tomography may in future overcome these limitations, but currently only prototype commercial systems are available [57]. In addition, the majority of the published studies were of small sample size and mostly cross sectional, limiting the interpretation and the general applicability of the results. To truly characterize retinal perfusion in patients with diabetes, studies in larger cohorts as well as longitudinal trials are warranted.

\section{Regulation of Retinal Blood Flow}

It is known for decades that the human retina is a metabolically demanding tissue. Thus, small alterations in blood flow and/or oxygen or shortage of nutrients may lead to an impaired supply of the tissue and, in turn, to hypoxia and a subsequent risk of tissue damage [58]. Conversely, exposure of tissue to hyperperfusion and/or high oxygen tension may lead to an increased formation of reactive oxygen species again followed by tissue dysfunction and cell death [59]. As such, it does not come as a surprise that ocular blood flow is highly regulated in response to changes in ocular perfusion pressure and metabolic factors $[9,60,61]$. For example, changes in systemic blood pressure or intraocular pressure [62] lead to an autoregulatory response of the ocular vasculature, thereby adapting vascular resistance in order to keep blood flow constant [61].

Metabolic regulation of retinal blood flow has also been reported, and vascular tone is sensitive to changes in $\mathrm{O}_{2}$ and/or $\mathrm{CO}_{2}$ : The retinal circulation adapts its blood flow to changes in blood $\mathrm{O}_{2}$ and $\mathrm{CO}_{2}$ levels to compensate for changes in blood gas concentrations. High $\mathrm{O}_{2}$ levels lead to a pronounced decrease in retinal vessel diameter and blood flow in order to prevent excessive oxygen supply to the retina [11,63]. Hypercapnia leads to vasodilation and an increased perfusion of the retina [64], an effect that is also well established for the brain. Retinal blood flow is, however, not only regulated in response to changes in perfusion pressure and oxygen but also in dependence on local neural activity, which is usually referred to as neurovascular coupling or functional hyperemia.

\section{The Concept of Neurovascular Coupling}

The first description that blood flow in neuronal tissues can be adapted to changes in local metabolic demands comes from the brain. In their landmark paper from 1890, Roy and Sherrington have hypothesized that the brain possesses an intrinsic mechanism that allows for the adaptation of blood flow to changes in neural activity with high spatial and temporal resolution [65]. This coupling mechanism between neural activity and blood flow is referred to as functional hyperemia or neurovascular coupling $[66,67]$. According to the current scientific view, functional hyperemia ensures adequate 
supply of the working tissue with nutrients and oxygen to cover the local energy demand of the firing neurons in correspondence to their functional activity.

Today, most of the evidence regarding the role of neurovascular coupling in health and disease stems from brain research. Modern functional brain imaging capabilities such as positron emission tomography (PET) or functional resonance imaging [68] have proven the theory of neurovascular coupling by showing that increased neural activity in the brain is accompanied by a pronounced and highly localized increase of local blood flow [69-71].

However, despite more than 25 years of intensive research, the cellular mechanisms mediating the coupling between neural activity and blood flow in the brain are not fully understood and remain controversial. It has recently become clear that the process of functional hyperemia requires a highly complex communication between different cell types and tissues involving neurons, glia cells, and blood vessels, with glia cells playing a central role in the signal pathway [67]. This complex regulation system ending up in the pericytes and the vascular smooth muscle cells is usually referred to as the "neurovascular unit" (Figure 3) [72].

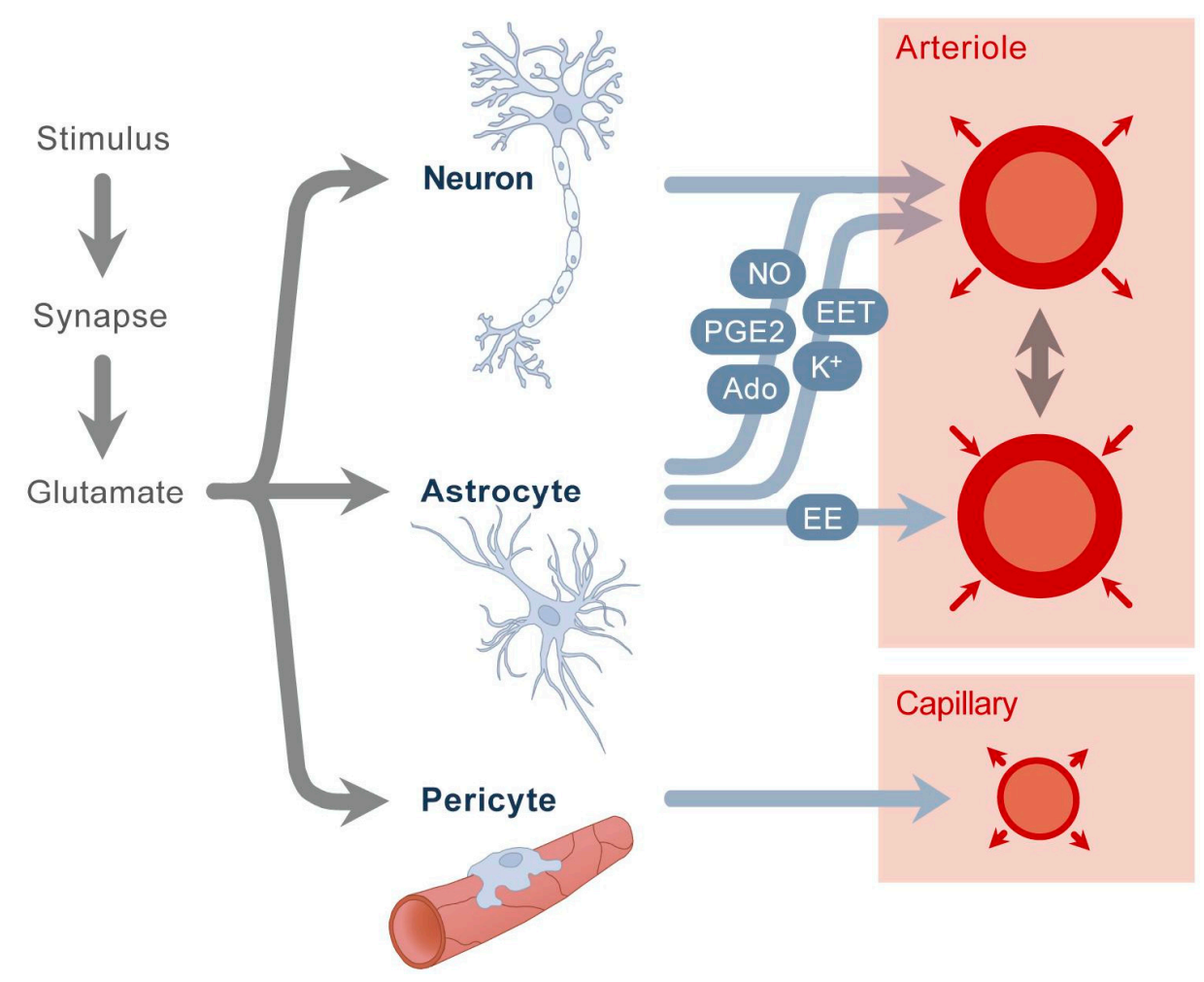

Figure 3. Neurovascular unit. A stimulus causes increased workload of neurons, which triggers a cascade of different events. Glutamate stimulates neurons and astrocytes, releasing nitric oxide (NO), potassium $\left(\mathrm{K}+\right.$ ), adenosine (Ado), epoxyeicosatrienoic acids (EETs), and prostaglandins (PG $\mathrm{E}_{2}$ ). Astrocytes also secrete arachidonic acid (EE), which causes vasoconstriction. A second mechanism is the stimulation of pericytes, resulting in capillary vasodilation. Modified from [73] with permission.

In the past, both metabolic feedback mechanisms as well as activity-dependent feed-forward mechanisms have been differentially discussed as potential pathways to mediate functional hyperemia in the brain. As such, activity-induced local increases in $\mathrm{CO}_{2}$, proton concentrations, or the release of lactate has been proposed as a metabolic trigger for the release of vasoactive agents $[74,75]$. However, whether and to what extent these metabolic changes contribute to the regulation processes warrants further investigation. Alternatively, activity-induced release of neurotransmitters by firing neurons has been hypothesized to activate blood flow. According to this so-called feed-forward mechanism, neuromodulatory agents such as $\mathrm{K}^{+}$and/or others may initiate a signaling network 
including nitric oxide (NO), prostanoids, and others that regulate vascular tone in dependence on neural work load $[67,76]$.

It has also been hypothesized that several parallel signaling pathways need to be involved in mediating functional hyperemia in the brain to maintain energy balance. This ensures that the brain can compensate for an impaired pathway by recruiting other alternative signaling cascades. An in-depth discussion of the exact molecular mechanism behind this regulation process in the brain is beyond the scope of this article, and the reader is referred to recent review articles $[67,77,78]$.

\subsection{Neurovascular Coupling in the Retina}

As the retina is a tissue of neural origin, it does not come as a surprise that neurovascular coupling can also be observed in the retina [12,79]. These similarities also apply to the molecular mechanisms that underly functional hyperemia at the level of the retinal microcirculation. Experimental evidence from rodent animal models indicates that neurovascular coupling in the retina is also largely mediated by glia cells $[80,81]$. Müller cells and astrocytes are the principal glia cells of the retina and optic nerve head. When stimulated, they release vasoactive agents such as prostaglandins (PG), epoxyeicosatrienoic acids, and 20-hydroxy-eicosatetraenoic acids, leading to vasodilatation [80]. Along this line of thought, it has been shown that interruption of signaling from neurons to glial cells reduces the flicker-induced hyperemic response [80].

Nitric oxide (NO), a potent vasodilator, has been shown to play a modulatory role in the mediation of functional hyperemia. Early experiments using invasive techniques for the assessment of $\mathrm{NO}$ in animal studies revealed an increase in local NO concentration during photic stimulation [82,83]. Blocking NO-synthase by NG-monomethyl-L-arginine significantly reduces flicker-induced vasodilatation in both animals and humans [84]. More recent animal studies indicate that NO does not directly mediate flicker-induced hyperemia but exerts a complex modulatory function [80]. NO interacts with glia cells and is involved in the regulation of the release of vasodilatation agents, most importantly PG $\mathrm{E}_{2}$ [85]. A detailed summary of the current understanding of the cellular mechanisms underlying neurovascular coupling in the retina has been published $[12,86,87]$.

\subsection{Neurovascular Coupling and Retinal Blood Flow}

It is generally accepted that increased retinal neural activity induced by photic stimulation, i.e., with flickering light, is associated with a pronounced and immediate hyperemic response. Experimental evidence indicates that this functional hyperemia can be observed in both the vascular bed of the optic nerve head as well as in the retinal circulation. Numerous studies using laser Doppler flowmetry (LDF) to assess optic nerve head perfusion consistently report that blood flow almost doubles in response to stimulation with flicker light in both experimental animal models [88] and humans [89].

The effect of photic stimulation on retinal vessel calibers is also well described. Studies investigating neurovascular coupling in both animals and humans report that stimulation with flickering light is accompanied by a vasodilation of retinal vessels in the range of approximately 3-5\% [90-92]. Interestingly, this increase in vessel calibers consistently occurs very rapidly after the onset of photic stimulation [93]. More specifically, the flicker profile follows a specific distinct pattern: For retinal arteries, a rapid vasodilation, which mostly occurs within the first 5-10 s of light stimulation is followed by a maintenance phase where the diameter is mostly stable (Figure 4). Upon cessation of the flicker stimulation, diameters rapidly drop below baseline before slowly returning back to the original values $[93,94]$. In contrast to retinal arteries, retinal veins lack a transient vasoconstrictor response and slowly return back to baseline values [93]. The reason for this behavior is unclear but may be related to different regulatory mechanism with different time-courses involved in the hyperemic response of retinal vessels. 


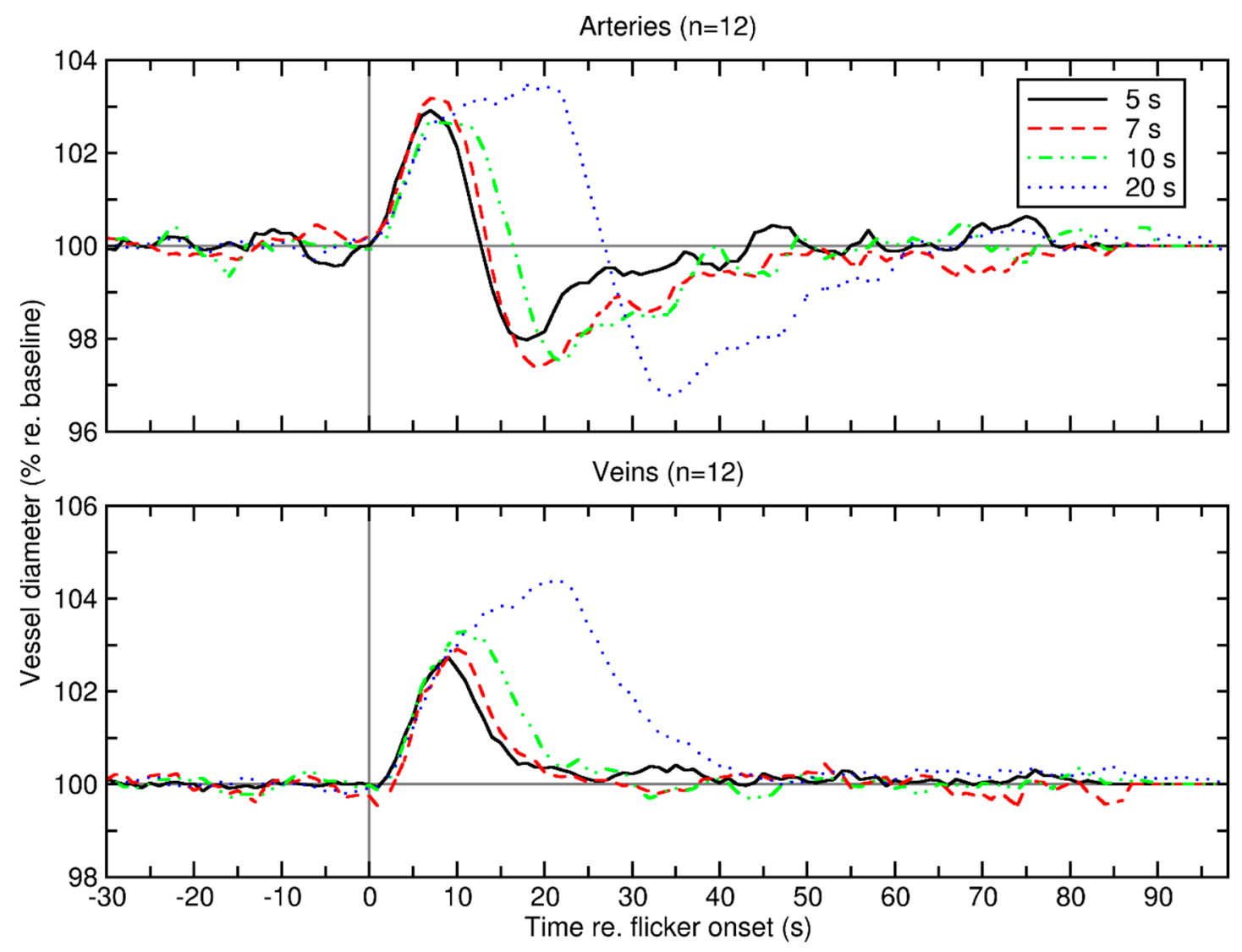

Figure 4. Average retinal vessel diameter of 12 healthy subjects before, during, and after secession of retinal vessel diameter for arteries (top panel) and veins (bottom panel). Different colors represent 4 different lengths of stimulation duration $(5,7,10$, and $20 \mathrm{~s})$. Vertical gray line denotes flicker onset; horizontal gray line denotes baseline diameter normalized to $100 \%$. Reproduced from [93] with permission.

Interestingly, the hyperemic response to flicker stimulation seems to be rather stable and is largely independent of changes in intraocular pressure or ocular perfusion pressure. Experimental evidence shows that a short-term increase in intraocular pressure of up to approximately $40 \mathrm{mmHg}$ does not block or alter the flicker-induced hyperemia in either the retina or the optic nerve head [95]. Similarly, acute increases of perfusion pressure, such as for example that induced by isometric exercise, do not induce a major effect on the flicker-induced vasodilatation in humans [96].

Additionally, the flicker response in both the retinal circulation as well as the optic nerve head is independent of stimulation frequency and modulation depth of the stimulus within a relatively wide range. Although studies that systemically investigate the influence of different stimulation patterns and modulation depths are sparse, early experimental data from feline animal models indicate a band pass shape of flicker responses with an almost stable optic nerve head blood flow response in the frequency range between $5 \mathrm{~Hz}$ and $20 \mathrm{~Hz}[97,98]$. Accordingly, the same studies report that flicker response is rather stable over large ranges of modulation depths, starting at approximately $10 \%$ of modulation depth with a saturation at $50 \%[97,98]$. Since the latter results closely resemble the functional responses of retinal ganglion cells, the findings support the hypothesis that flicker-induced hyperemia is mainly dependent on increased retinal ganglion activity [12].

As for human experiments, the vast majority of studies published in the literature used either square-wave-modulated flicker lights or flashlight stimulations to investigate flicker-induced hyperemia. Given that the influence of modulation depth, wavelength, and frequency on flicker response has not been thoroughly investigated, there is currently no certainty regarding the optimal stimulation pattern in humans. Polak and colleagues have investigated the influence of flicker frequency on flicker-induced 
changes of retinal vessel diameter in humans. The authors report that in all tested flicker frequencies between 2 and $64 \mathrm{~Hz}$ flicker-induced vasodilatations were observed with a more pronounced response in retinal arteries compared to that in retinal veins [94]. However, in this study, short-wavelength chromatic flicker was used to separate stimulation light from the illumination pathway of the measuring system. Results indicate that both parvo- and magnocellular neural pathways are activated during flicker stimulation, which highlights the importance of the selected wavelength range for visual stimulation [99].

Mainly because of technical restrictions, most of the previously mentioned studies have focused on the response of retinal vessel diameters to investigate neurovascular coupling and draw conclusions on flow changes. More sophisticated technical approaches allow, however, not only for the assessment of retinal vessel calibers but for the direct determination of blood flow changes during flicker stimulation. Assessing volumetric blood flow by a combination of Laser Doppler Velocimetry and retinal vessel analysis has shown that retinal blood flow in major retinal vessels increases by more than $50 \%$ during visual stimulation [100], which is slightly higher compared to the data obtained for the optic nerve head [89]. Given that this approach requires excellent cooperation of the subject and is very time demanding, this technique is not suitable for clinical use to investigate functional hyperemia in patients.

However, the rapid development in ocular imaging may in future enable us to overcome the latter limitations. As such, more recently, optical technologies have emerged that allow for the measurement of retinal perfusion based on functional optical coherence tomography (OCT). Using dual-beam bidirectional Doppler Fourier Domain OCT (D-OCT), it has been shown that total retinal blood flow increases by approximately $50 \%$ in response to flicker light stimulation, which is in line with results obtained using other methods [101]. The data of the latter study report individual increases in total retinal blood flow between $34 \%$ and $66 \%$ [101]. Although the reason for the high inter-subject variability is unclear, it may be related to the differences in the angio-architecture and the variability of total retinal blood flow per se [102]. However, as the D-OCT technique is not yet commercially available, its use is currently limited to specialized laboratories.

Another method that has recently gained interest as a non-invasive method to assess neurovascular coupling in humans is laser speckle flowgraphy (LSFG). As shown previously with other techniques, the LSFG technique allows the quantification of flicker-induced hyperemia in the retinal circulation and the optic nerve head [103]. This technique is also commercially available and may in future be used as a non-invasive, easy-to-use tool to assess neurovascular coupling in humans.

\subsection{Neurovascular Coupling in Diabetes}

Convincing data across studies show that neurovascular coupling is impaired in patients with diabetes. Using fMRI and other functional imaging techniques for the brain, there is compelling evidence that there is an uncoupling between neural activity and blood flow in brain microcirculation in patients with diabetes mellitus, which in turn may trigger clinical consequences such as the cognitive impairment frequently observed in patients with type II diabetes [104,105].

As for the retina, it has been shown that vascular dilatation evoked by flicker stimulation is reduced in both patients with type I and type II diabetes when compared to that in healthy, non-diabetic subjects [106-109]. Some of these studies indicate that alterations in flicker-induced vasodilatation is evident also in early stages of diabetes with no or minimal diabetic retinopathy [106,107].

These results are also consistent with data from a larger trial, investigating a cohort of approximately 200 patients with type II diabetes [110] demonstrating that the flicker-induced vasodilatation of both retinal arteries and veins is abnormal even in patients without diabetic retinopathy, strongly suggesting that abnormal neurovascular coupling precedes a visible angiopathy in humans. Furthermore, the authors report that the flicker response deteriorates with increasing stages of diabetic retinopathy, which indicates that the impairment of functional hyperemia is dependent on the severity of the disease (Figure 5) [110]. 


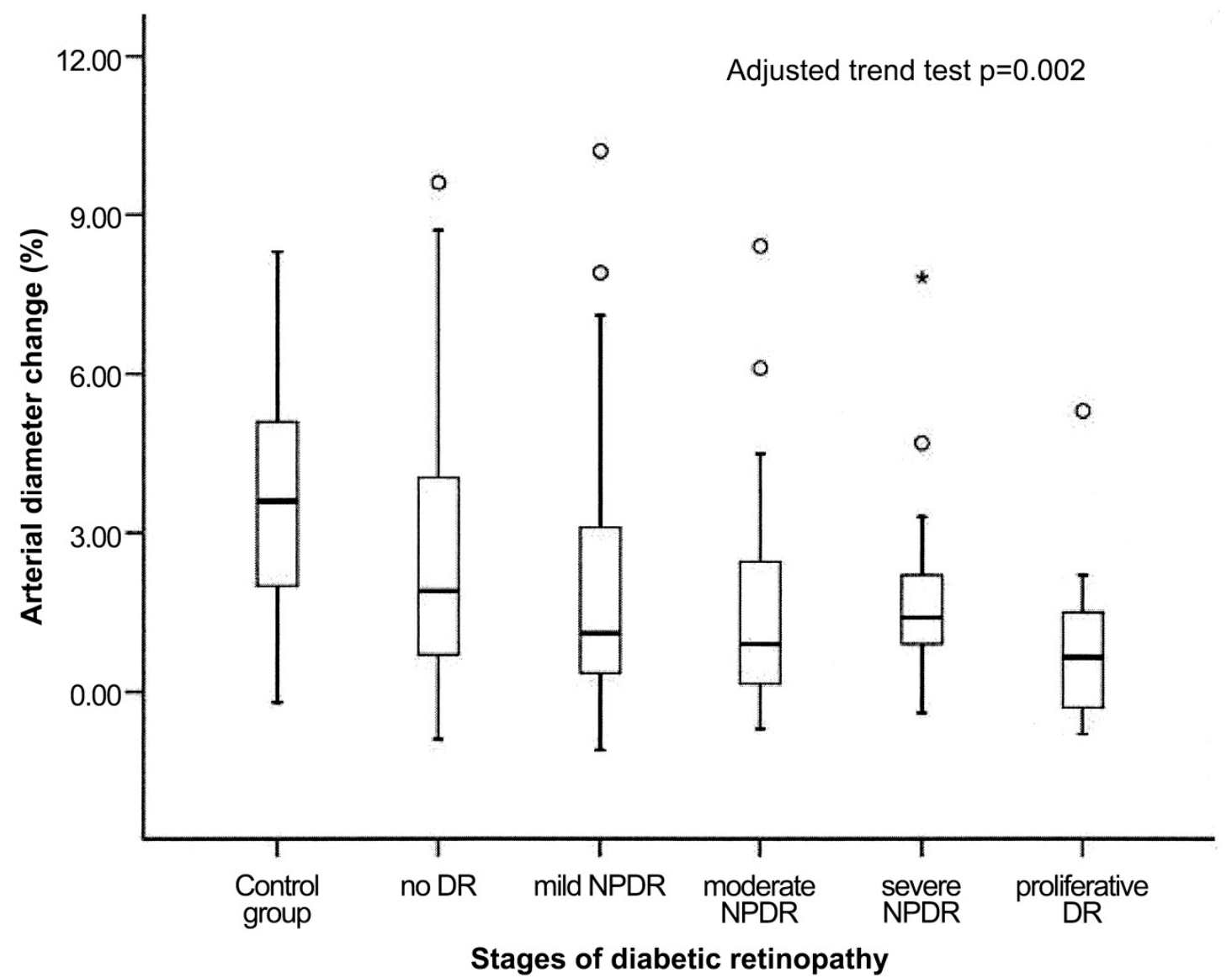

Figure 5. Flicker-induced vasodilatation of retinal arterial diameters as percent change from baseline in healthy subjects (control group) and different severities of diabetic retinopathy (DR = diabetic retinopathy, NPDR = non-proliferative diabetic retinopathy). Circles represent outliers and the asterisk represents an extreme outlier. From [110] with permission.

In the previous study [110], no adjustment for potential confounding systemic factors such as smoking, fasting glucose, and blood pressure was performed. Factors such as insufficient glycemic control [111,112], chronic systemic hypertension [113] or hypercholesteremia [114] may, however, per se lead to an impaired flicker response. Taking into account these potentially biasing factors, data from a cross-sectional study including 224 individuals with diabetes and more than 100 healthy controls confirmed that functional hyperemia is reduced in patients with diabetes [115]. In particular, the authors showed that after adjustment for age, sex, diabetes duration, fasting glucose, cholesterol and triglyceride levels, current smoking status, systolic blood pressure, and use of antihypertensive and lipid-lowering medications, subjects with low flicker responses were more likely to have diabetes [115]. In addition, it is reported by the same group of authors that reduced flicker-induced vasodilation is associated with a wider retinal vascular caliber [116].

Given that diabetic retinopathy displays regional differences in respect to the occurrence of retinopathy lesions, it has been hypothesized that these differences may be caused by regional loss of the neurovascular coupling, in particular in the periphery of the retina [117].Indeed, cross-sectional studies report regional differences in flicker-induced hyperemia in patients with diabetic retinopathy [117] and patients with diabetic macular edema (DME) [118]. Although the data of the latter studies indicate that there is a generally diminished response in patients with proliferative diabetic retinopathy [117] and DME [118], the authors suggest that central retinal areas might be less affected by impaired blood flow regulation processes than more peripheral regions. Whether this hypothesis holds truth or whether the results are related to the peripheral dropout of vessels has yet to be determined. 
In contrast to the large variety of studies mentioned above, one study did not find an attenuated flicker responses in patients with type 2 diabetes when compared to a healthy, age-matched control group [119]. However, this trial included 20 patients only and may, therefore, be underpowered to detect differences between healthy and diabetic subjects.

Retinal flicker-induced hyperemia has also been investigated in different diabetic animal models including rats and mice. These experiments show that in streptozotocin-induced rat models of type 1 diabetes flicker-induced hyperemia is reduced by more than $50 \%$, which is well compatible with the results obtained in humans $[81,85,120]$. The loss of functional hyperemia can be reversed by the administration of inducible nitric oxide synthase (iNOS) inhibitors [81,85].

Although there is compelling evidence that flicker-induced hyperemia is reduced in subjects with diabetes, the molecular mechanisms behind this altered response are poorly understood. As stated previously, NO seems to have a central modulating role during functional hyperemia, most probably by regulating glial release of EETs and $\mathrm{PGE}_{2}$ [80]. Data from human studies suggest that NO may also play a role in the altered functional hyperemic response in patients with diabetes. In particular, an interventional study provides evidence that administration of the NOS inhibitor L-NMMA leads to an increase in flicker-induced vasodilation in patients with diabetic macula edema [118]. Whether this is related to an increased NO concentration at the level of the retina in patients with diabetes needs to be clarified in further studies.

Further, it has been suggested that the attenuation of flicker response found in patients with diabetes is consistent with endothelial dysfunction [110,115]. According to this hypothesis, the loss of the hyperemic response may be a direct consequence of impaired endothelium-dependent dilatation on the microvascular level. In patients with type I and type II diabetes, reduced endothelial-dependent vasodilatation was shown in several clinical studies using plethysmography of the brachial or femoral arteries [121,122].

Indeed, patients with known endothelial dysfunction, such as chronic smokers [123], those with hypercholesteremia [113] or patients with systemic hypertension [114] show reduced hyperemic responses to flicker stimulation. Interestingly, a study testing the general vasodilatation response of retinal vessels by the exogenous administration of glyceryl trinitrate, a potent endothelium-independent $\mathrm{NO}$ donor, revealed that the response of retinal vessels to NO is preserved in patients with type II diabetes [124]. This indicates that abnormal flicker-induced vasodilatation in diabetes is not a consequence of generally reduced retinal vascular reactivity but is due to compromised intrinsic mechanisms that promote functional hyperemia [124]. One study investigating a potential correlation between flicker-induced vasodilatation and other systemic measures of endothelial function such as flow-mediated vasodilatation (FMD), failed to show a strong correlation between FMD and flicker response [125]. Whether this is related to the different vascular beds measured or the stimulus used has yet to be investigated.

Considering the latter findings, it has been hypothesized that a reduced "vasodilatory reservoir" or the inability of vessels to further dilate in already dilated retinal arterioles and venules in patients with diabetes causes a decrease in flicker response [126]. As stated above, this hypothesis is strengthened by the observation that venous dilatation is frequently observed in patients with diabetes. However, as vasodilatation induced by external nitric oxide is preserved in predilated vessels of patients with diabetes [124], it seems unlikely that reduced flicker responses can be solely attributed to different baseline vessel calibers.

Finally, impaired neuronal function may contribute to the diminished flicker response found in patients with diabetes. It has been hypothesized that beside microvascular changes, neuroglial impairment may be involved early in the disease process [127]. Retinal oscillatory potentials, which are an early functional retinal abnormality in patients with diabetes, negatively correlate with retinal arteriolar caliber indicating a close relationship between neuronal microvasculature dysfunction in the retina [128]. Müller cells, which play an important role in mediating neural activity, are affected early in diabetes and exhibit different pathological properties such as the diminution of potassium 
channels and an impairment of intracellular fluid transportation [129]. Based on these observations, it is reasonable to suggest that impaired neural activity, reduced glia cell activation, and an impaired signal transduction contribute to reduced flicker-induced vasodilatation.

Along this line of thought, Lecleire-Collet and co-workers investigated a potential correlation between neural-activity and flicker-induced retinal vasodilation in patients with diabetes and healthy controls [107]. Although the authors found an overall correlation between flicker-light-induced arterial vasodilatation and pattern electroretinography (ERG) in the whole study group, no correlation was observed when only diabetic patients were considered. Another study investigated pattern electroretinography and flicker-induced vasodilatation in a group of 50 patients with type I diabetes without any signs of retinopathy and 50 age- and sex-matched healthy control subjects [130]. This study confirmed previous results of diminished flicker-induced vasodilation in patients with no visible diabetic retinopathy; no difference was found in terms of pattern ERG between groups. This indicates that the abnormal retinal hyperemic response is unlikely to be a consequence of reduced neuronal activity but rather precedes ERG changes. Further research investigating the role of neuroglia cells and their potential influence on neurovascular coupling is required. Additionally, longitudinal studies may add information regarding the time-course of neural and endothelial dysfunction in patients with diabetes.

\subsection{Neurovascular Coupling in Other Diseases}

As stated previously, a breakdown of neurovascular coupling is not specific to patients with diabetes. Several studies have shown that neurovascular coupling is dependent on age [131-133]. Using functional MRI, data from the brain indicate that neurovascular coupling blood flow responses are reduced in older adults compared to those in younger subjects [133]. This is in keeping with experimental evidence from rodent models showing a significant impairment of neurovascular coupling in animals with advanced age $[134,135]$. Thus, it has been hypothesized that a breakdown of neurovascular coupling may exacerbate cognitive decline during aging [66]. Interestingly, selective pharmacological blocking of neurovascular coupling in young healthy animals leads to a pronounced impairment of cognitive and sensorimotor function [136] whereas rescue of functional hyperemia is associated with significantly improved spatial working memory and learning [137]. This supports the hypothesis that an age-related impairment of neurovascular coupling in the brain plays a causal role in the pathogenesis of dementia.

For the retina, the data regarding the age dependence of neurovascular coupling is less clear. In a study investigating the effect of age, blood pressure, and baseline retinal vessel diameter, the authors did not find a correlation between age and flicker-induced vasodilation [113]. In contrast, investigating flicker-induced vasodilatation in the human retina, Lipecz and colleagues report that individuals with an age of 65 years or more have diminished flicker responses compared to a younger control group at the age of 45 or less [132]. Further studies are required to investigate the associate between aging and neurovascular coupling in the retina.

Additionally, it has been previously shown that a reduction of the functional hyperemic response of retinal vessels can also be observed in patients with other ocular diseases. As such, there is ample evidence that patients with glaucoma show a reduction of flicker-induced vasodilation [138-141]. In addition, it has been shown that a decline in flicker response is also present in patients with systemic vascular diseases such as systemic hypertension [113] or hypercholesterolemia [114]. Attempts have also been made to use neurovascular coupling as a potential biomarker for neurodegenerative diseases of the brain. Although one study found an increase in flicker response in patients with Alzheimer's disease [142], another study failed to find a difference in flicker-induced hyperemia in patients with Alzheimer's disease and mild cognitive impairment [143]. 


\section{Further Studies}

Most of the studies investigating neurovascular coupling in patients with diabetes are cross-sectional and have included only a limited number of participants. Although cross-sectional studies indicate stage-dependence of the reduction in functional hyperemia, longitudinal data from large, multicentric studies are currently lacking. This is also related to the fact that currently no gold standard for the measurement of retinal blood flow is available. The assessment of neurovascular coupling in humans is technically demanding and only available in specialized research centers. However, the rapid technical development of new functional imaging methods such as functional optical coherence tomography may, in future, allow for the easy and non-invasive assessment of volumetric blood flow also in clinical settings.

Additionally, it is unclear whether patients with earlier or more pronounced uncoupling of neuronal activity and blood flow are at a higher risk for the progression or development of diabetes-associated complications. If so, this would allow for the use of functional hyperemia to identify high-risk patients and/or the use of functional hyperemia as a surrogate parameter for disease progression. Further, studies investigating the mechanism of neurovascular breakdown in diabetes are required.

\section{Conclusions}

Neurovascular coupling is one of the key physiological mechanisms that allow for the adaptation of the retinal vascular system to changing neural function and increased metabolic demand. Although the exact molecular mechanisms behind this functional hyperemic response warrant further investigation, there is general agreement that an impairment of neurovascular coupling is an early event in several ocular and systemic diseases including diabetic retinopathy. Thus, it is reasonable to suggest that an impaired response to increased metabolic demand might trigger further detrimental consequences such as focal ischemia or insufficient removal of metabolic waste products. Further research is needed to develop an accurate model of the regulation of blood flow in the eye to allow for a better understanding of why blood flow is compromised in patients with diabetes. In addition, the observation made in animal models that impaired neurovascular response can be at least partially restored by modulating the messengers within the neurovascular unit opens new perspectives on drug targets for early pharmacological interventions before the full clinical picture of the disease is established. Finally, as the breakdown of neurovascular coupling is an early event in the disease process, impaired functional hyperemia might be used as a surrogate parameter for the identification of high-risk patients as well as for the follow-up of treatment outcomes. However, longitudinal studies are required to further investigate neurovascular coupling during the disease process.

Author Contributions: G.G. and L.S. wrote the manuscript, J.C., B.T., D.W. and D.S. critically revised the manuscript. All authors have read and agreed to the published version of the manuscript.

Funding: This work was funded by the Austrian Science Foundation FWF Project KLIF721.

Conflicts of Interest: The authors declare no conflict of interest.

\section{References}

1. Beckman, J.A.; Creager, M.A. Vascular Complications of Diabetes. Circ. Res. 2016, 118, 1771-1785. [CrossRef] [PubMed]

2. Herman, W.H. Diabetes epidemiology: Guiding clinical and public health practice: The Kelly West Award Lecture, 2006. Diabetes Care 2007, 30, 1912-1919. [CrossRef]

3. Maahs, D.M.; West, N.A.; Lawrence, J.M.; Mayer-Davis, E.J. Epidemiology of type 1 diabetes. Endocrinol. Metab. Clin. North Am. 2010, 39, 481-497. [CrossRef] [PubMed]

4. Wang, W.; Lo, A.C.Y. Diabetic Retinopathy: Pathophysiology and Treatments. Int. J. Mol. Sci. 2018, 19. [CrossRef] [PubMed]

5. Arden, G.B.; Sivaprasad, S. Hypoxia and oxidative stress in the causation of diabetic retinopathy. Curr. Diabetes Rev. 2011, 7, 291-304. [CrossRef] [PubMed] 
6. Pemp, B.; Schmetterer, L. Ocular blood flow in diabetes and age-related macular degeneration. Can. J. Ophthalmol. 2008, 43, 295-301. [CrossRef] [PubMed]

7. Stitt, A.W.; Curtis, T.M.; Chen, M.; Medina, R.J.; McKay, G.J.; Jenkins, A.; Gardiner, T.A.; Lyons, T.J.; Hammes, H.P.; Simo, R.; et al. The progress in understanding and treatment of diabetic retinopathy. Prog. Retin. Eye Res. 2016, 51, 156-186. [CrossRef]

8. Flammer, J.; Mozaffarieh, M. Autoregulation, a balancing act between supply and demand. Can. J. Ophthalmol. 2008, 43, 317-321. [CrossRef]

9. Luo, X.; Shen, Y.M.; Jiang, M.N.; Lou, X.F.; Shen, Y. Ocular Blood Flow Autoregulation Mechanisms and Methods. J. Ophthalmol. 2015, 2015, 864871. [CrossRef]

10. Cheng, R.W.; Yusof, F.; Tsui, E.; Jong, M.; Duffin, J.; Flanagan, J.G.; Fisher, J.A.; Hudson, C. Relationship between retinal blood flow and arterial oxygen. J. Physiol. 2016, 594, 625-640. [CrossRef]

11. Palkovits, S.; Lasta, M.; Told, R.; Schmidl, D.; Boltz, A.; Napora, K.J.; Werkmeister, R.; Popa-Cherecheanu, A.; Garhofer, G.; Schmetterer, L. Retinal oxygen metabolism during normoxia and hyperoxia in healthy subjects. Invest. Ophthalmol. Vis. Sci. 2014. [CrossRef] [PubMed]

12. Newman, E.A. Functional hyperemia and mechanisms of neurovascular coupling in the retinal vasculature. J. Cereb. Blood Flow Metab. 2013. [CrossRef] [PubMed]

13. Shabir, O.; Berwick, J.; Francis, S.E. Neurovascular dysfunction in vascular dementia, Alzheimer's and atherosclerosis. BMC Neurosci. 2018, 19, 62. [CrossRef] [PubMed]

14. Mogi, M.; Horiuchi, M. Neurovascular coupling in cognitive impairment associated with diabetes mellitus. Circ. J. 2011, 75, 1042-1048. [CrossRef] [PubMed]

15. Pemp, B.; Cherecheanu, A.P.; Garhofer, G.; Schmetterer, L. Calculation of central retinal artery diameters from non-invasive ocular haemodynamic measurements in type 1 diabetes patients. Acta Ophthalmol. 2013, 91, e348-e352. [CrossRef]

16. Li, Y.; Xia, X.; Paulus, Y.M. Advances in Retinal Optical Imaging. Photonics 2018, 5. [CrossRef]

17. McGeechan, K.; Liew, G.; Macaskill, P.; Irwig, L.; Klein, R.; Klein, B.E.; Wang, J.J.; Mitchell, P.; Vingerling, J.R.; Dejong, P.T.; et al. Meta-analysis: Retinal vessel caliber and risk for coronary heart disease. Ann. Intern. Med. 2009, 151, 404-413. [CrossRef]

18. Liew, G.; Wang, J.J.; Mitchell, P.; Wong, T.Y. Retinal vascular imaging: A new tool in microvascular disease research. Circ. Cardiovasc. Imaging. 2008, 1, 156-161. [CrossRef]

19. Mimoun, L.; Massin, P.; Steg, G. Retinal microvascularisation abnormalities and cardiovascular risk. Arch. Cardiovasc. Dis. 2009, 102, 449-456. [CrossRef]

20. McClintic, B.R.; McClintic, J.I.; Bisognano, J.D.; Block, R.C. The relationship between retinal microvascular abnormalities and coronary heart disease: A review. Am. J. Med. 2010, 123, e371-e377. [CrossRef]

21. Ikram, M.K.; Cheung, C.Y.; Lorenzi, M.; Klein, R.; Jones, T.L.; Wong, T.Y.; Group, N.J.W.o.R.B.f.D. Retinal vascular caliber as a biomarker for diabetes microvascular complications. Diabetes Care 2013, 36, 750-759. [CrossRef] [PubMed]

22. Wong, T.Y.; Knudtson, M.D.; Klein, R.; Klein, B.E.; Meuer, S.M.; Hubbard, L.D. Computer-assisted measurement of retinal vessel diameters in the Beaver Dam Eye Study: Methodology, correlation between eyes, and effect of refractive errors. Ophthalmology 2004, 111, 1183-1190. [CrossRef] [PubMed]

23. Hubbard, L.D.; Brothers, R.J.; King, W.N.; Clegg, L.X.; Klein, R.; Cooper, L.S.; Sharrett, A.R.; Davis, M.D.; Cai, J. Methods for evaluation of retinal microvascular abnormalities associated with hypertension/sclerosis in the Atherosclerosis Risk in Communities Study. Ophthalmology 1999, 106, 2269-2280. [CrossRef]

24. Wong, T.Y.; Klein, R.; Sharrett, A.R.; Schmidt, M.I.; Pankow, J.S.; Couper, D.J.; Klein, B.E.; Hubbard, L.D.; Duncan, B.B.; Investigators, A. Retinal arteriolar narrowing and risk of diabetes mellitus in middle-aged persons. JAMA 2002, 287, 2528-2533. [CrossRef]

25. Wong, T.Y.; Shankar, A.; Klein, R.; Klein, B.E.; Hubbard, L.D. Retinal arteriolar narrowing, hypertension, and subsequent risk of diabetes mellitus. Arch. Intern. Med. 2005, 165, 1060-1065. [CrossRef]

26. Nguyen, T.T.; Wang, J.J.; Islam, F.M.; Mitchell, P.; Tapp, R.J.; Zimmet, P.Z.; Simpson, R.; Shaw, J.; Wong, T.Y. Retinal arteriolar narrowing predicts incidence of diabetes: The Australian Diabetes, Obesity and Lifestyle (AusDiab) Study. Diabetes 2008, 57, 536-539. [CrossRef]

27. Nguyen, T.T.; Wang, J.J.; Sharrett, A.R.; Islam, F.M.; Klein, R.; Klein, B.E.; Cotch, M.F.; Wong, T.Y. Relationship of retinal vascular caliber with diabetes and retinopathy: The Multi-Ethnic Study of Atherosclerosis (MESA). Diabetes Care 2008, 31, 544-549. [CrossRef] 
28. Kifley, A.; Wang, J.J.; Cugati, S.; Wong, T.Y.; Mitchell, P. Retinal vascular caliber and the long-term risk of diabetes and impaired fasting glucose: The Blue Mountains Eye Study. Microcirculation 2008, 15, 373-377. [CrossRef]

29. Ikram, M.K.; Janssen, J.A.; Roos, A.M.; Rietveld, I.; Witteman, J.C.; Breteler, M.M.; Hofman, A.; van Duijn, C.M.; de Jong, P.T. Retinal vessel diameters and risk of impaired fasting glucose or diabetes: The Rotterdam study. Diabetes 2006, 55, 506-510. [CrossRef]

30. Sabanayagam, C.; Lye, W.K.; Klein, R.; Klein, B.E.; Cotch, M.F.; Wang, J.J.; Mitchell, P.; Shaw, J.E.; Selvin, E.; Sharrett, A.R.; et al. Retinal microvascular calibre and risk of diabetes mellitus: A systematic review and participant-level meta-analysis. Diabetologia 2015, 58, 2476-2485. [CrossRef]

31. Phan, K.; Mitchell, P.; Liew, G.; Plant, A.J.; Wang, S.B.; Thiagalingam, A.; Burlutsky, G.; Gopinath, B. Associations between retinal arteriolar and venular calibre with the prevalence of impaired fasting glucose and diabetes mellitus: A cross-sectional study. PLoS ONE 2018, 13, e0189627. [CrossRef] [PubMed]

32. Nguyen, T.T.; Wong, T.Y. Retinal vascular changes and diabetic retinopathy. Curr. Diab. Rep. 2009, 9, $277-283$. [CrossRef] [PubMed]

33. Cheung, C.Y.; Ikram, M.K.; Klein, R.; Wong, T.Y. The clinical implications of recent studies on the structure and function of the retinal microvasculature in diabetes. Diabetologia 2015, 58, 871-885. [CrossRef] [PubMed]

34. Antonetti, D.A.; Klein, R.; Gardner, T.W. Diabetic retinopathy. N. Engl. J. Med. 2012, 366, 1227-1239. [CrossRef]

35. Klein, R.; Meuer, S.M.; Moss, S.E.; Klein, B.E. Retinal microaneurysm counts and 10-year progression of diabetic retinopathy. Arch. Ophthalmol. 1995, 113, 1386-1391. [CrossRef]

36. Spaide, R.F.; Fujimoto, J.G.; Waheed, N.K.; Sadda, S.R.; Staurenghi, G. Optical coherence tomography angiography. Prog. Retin. Eye. Res. 2017. [CrossRef]

37. Battista, M.; Borrelli, E.; Sacconi, R.; Bandello, F.; Querques, G. Optical coherence tomography angiography in diabetes: A review. Eur. J. Ophthalmol. 2020, 30, 411-416. [CrossRef]

38. Freiberg, F.J.; Pfau, M.; Wons, J.; Wirth, M.A.; Becker, M.D.; Michels, S. Optical coherence tomography angiography of the foveal avascular zone in diabetic retinopathy. Graefes Arch. Clin. Exp. Ophthalmol. 2016, 254, 1051-1058. [CrossRef]

39. Al-Sheikh, M.; Akil, H.; Pfau, M.; Sadda, S.R. Swept-Source OCT Angiography Imaging of the Foveal Avascular Zone and Macular Capillary Network Density in Diabetic Retinopathy. Invest. Ophthalmol. Vis. Sci. 2016, 57, 3907-3913. [CrossRef]

40. Takase, N.; Nozaki, M.; Kato, A.; Ozeki, H.; Yoshida, M.; Ogura, Y. Enlargement of Foveal Avascular Zone in Diabetic Eyes Evaluated by En Face Optical Coherence Tomography Angiography. Retina 2015, 35, 2377-2383. [CrossRef]

41. Nesper, P.L.; Roberts, P.K.; Onishi, A.C.; Chai, H.; Liu, L.; Jampol, L.M.; Fawzi, A.A. Quantifying Microvascular Abnormalities With Increasing Severity of Diabetic Retinopathy Using Optical Coherence Tomography Angiography. Inves.t Ophthalmol. Vis. Sci. 2017, 58, BIO307-BIO315. [CrossRef] [PubMed]

42. Onishi, A.C.; Nesper, P.L.; Roberts, P.K.; Moharram, G.A.; Chai, H.; Liu, L.; Jampol, L.M.; Fawzi, A.A. Importance of Considering the Middle Capillary Plexus on OCT Angiography in Diabetic Retinopathy. Invest. Ophthalmol. Vis. Sci. 2018, 59, 2167-2176. [CrossRef]

43. Hirano, T.; Kitahara, J.; Toriyama, Y.; Kasamatsu, H.; Murata, T.; Sadda, S. Quantifying vascular density and morphology using different swept-source optical coherence tomography angiographic scan patterns in diabetic retinopathy. Br. J. Ophthalmol. 2019, 103, 216-221. [CrossRef] [PubMed]

44. Kim, A.Y.; Chu, Z.; Shahidzadeh, A.; Wang, R.K.; Puliafito, C.A.; Kashani, A.H. Quantifying Microvascular Density and Morphology in Diabetic Retinopathy Using Spectral-Domain Optical Coherence Tomography Angiography. Invest. Ophthalmol. Vis. Sci. 2016, 57, OCT362-OCT370. [CrossRef] [PubMed]

45. Lu, Y.; Simonett, J.M.; Wang, J.; Zhang, M.; Hwang, T.; Hagag, A.M.; Huang, D.; Li, D.; Jia, Y. Evaluation of Automatically Quantified Foveal Avascular Zone Metrics for Diagnosis of Diabetic Retinopathy Using Optical Coherence Tomography Angiography. Invest. Ophthalmol. Vis. Sci. 2018, 59, 2212-2221. [CrossRef] [PubMed]

46. Lei, J.; Yi, E.; Suo, Y.; Chen, C.; Xu, X.; Ding, W.; Abdelfattah, N.S.; Fan, X.; Lu, H. Distinctive Analysis of Macular Superficial Capillaries and Large Vessels Using Optical Coherence Tomographic Angiography in Healthy and Diabetic Eyes. Invest. Ophthalmol. Vis. Sci. 2018, 59, 1937-1943. [CrossRef] 
47. Chua, J.; Sim, R.; Tan, B.; Wong, D.; Yao, X.; Liu, X.; Ting, D.S.W.; Schmidl, D.; Ang, M.; Garhofer, G.; et al. Optical Coherence Tomography Angiography in Diabetes and Diabetic Retinopathy. J. Clin. Med. 2020, 9. [CrossRef]

48. Wei, X.; Balne, P.K.; Meissner, K.E.; Barathi, V.A.; Schmetterer, L.; Agrawal, R. Assessment of flow dynamics in retinal and choroidal microcirculation. Surv. Ophthalmol. 2018, 63, 646-664. [CrossRef]

49. Schmetterer, L.; Garhofer, G. How can blood flow be measured? Surv. Ophthalmol. 2007, 52 (Suppl. S2), S134-S138. [CrossRef]

50. Grunwald, J.E.; Brucker, A.J.; Grunwald, S.E.; Riva, C.E. Retinal hemodynamics in proliferative diabetic retinopathy. A laser Doppler velocimetry study. Invest. Ophthalmol. Vis. Sci. 1993, 34, 66-71.

51. Arend, O.; Wolf, S.; Jung, F.; Bertram, B.; Postgens, H.; Toonen, H.; Reim, M. Retinal microcirculation in patients with diabetes mellitus: Dynamic and morphological analysis of perifoveal capillary network. Br. J. Ophthalmol. 1991, 75, 514-518. [CrossRef] [PubMed]

52. Iwase, T.; Kobayashi, M.; Yamamoto, K.; Ra, E.; Terasaki, H. Effects of photocoagulation on ocular blood flow in patients with severe non-proliferative diabetic retinopathy. PLoS ONE 2017, 12, e0174427. [CrossRef] [PubMed]

53. Patel, V.; Rassam, S.; Newsom, R.; Wiek, J.; Kohner, E. Retinal blood flow in diabetic retinopathy. BMJ 1992, 305, 678-683. [CrossRef] [PubMed]

54. Pemp, B.; Polska, E.; Garhofer, G.; Bayerle-Eder, M.; Kautzky-Willer, A.; Schmetterer, L. Retinal blood flow in type 1 diabetic patients with no or mild diabetic retinopathy during euglycemic clamp. Diabetes Care 2010, 33, 2038-2042. [CrossRef]

55. Nguyen, H.T.; van Duinkerken, E.; Verbraak, F.D.; Polak, B.C.; Ringens, P.J.; Diamant, M.; Moll, A.C. Retinal blood flow is increased in type 1 diabetes mellitus patients with advanced stages of retinopathy. BMC Endocr. Disord. 2016, 16, 25. [CrossRef]

56. Fondi, K.; Wozniak, P.A.; Howorka, K.; Bata, A.M.; Aschinger, G.C.; Popa-Cherecheanu, A.; Witkowska, K.J.; Hommer, A.; Schmidl, D.; Werkmeister, R.M.; et al. Retinal oxygen extraction in individuals with type 1 diabetes with no or mild diabetic retinopathy. Diabetologia 2017, 60, 1534-1540. [CrossRef]

57. Leitgeb, R.A.; Werkmeister, R.M.; Blatter, C.; Schmetterer, L. Doppler optical coherence tomography. Prog. Retin. Eye Res. 2014, 41, 26-43. [CrossRef]

58. Linsenmeier, R.; Padnick-Silver, L. Metabolic dependence of photoreceptors on the choroid in the normal and detached retina. Invest. Ophthalmol. Vis. Sci. 2000, 41, 2678-2683.

59. McMonnies, C.W. Hyperbaric oxygen therapy and the possibility of ocular complications or contraindications. Clin. Exp. Optom. J. Aust. Optom. Assoc. 2015, 98, 122-125. [CrossRef]

60. Prada, D.; Harris, A.; Guidoboni, G.; Siesky, B.; Huang, A.M.; Arciero, J. Autoregulation and neurovascular coupling in the optic nerve head. Surv. Ophthalmol. 2016, 61, 164-186. [CrossRef]

61. Pournaras, C.J.; Rungger-Brandle, E.; Riva, C.E.; Hardarson, S.H.; Stefansson, E. Regulation of retinal blood flow in health and disease. Prog. Retin. Eye Res. 2008, 27, 284-330. [CrossRef] [PubMed]

62. Puchner, S.; Schmidl, D.; Ginner, L.; Augustin, M.; Leitgeb, R.; Szegedi, S.; Stjepanek, K.; Hommer, N.; Kallab, M.; Werkmeister, R.M.; et al. Changes in Retinal Blood Flow in Response to an Experimental Increase in IOP in Healthy Participants as Assessed With Doppler Optical Coherence Tomography. Invest. Ophthalmol. Vis. Sci. 2020, 61, 33. [CrossRef] [PubMed]

63. Luksch, A.; Garhofer, G.; Imhof, A.; Polak, K.; Polska, E.; Dorner, G.T.; Anzenhofer, S.; Wolzt, M.; Schmetterer, L. Effect of inhalation of different mixtures of $\mathrm{O}(2)$ and $\mathrm{CO}(2)$ on retinal blood flow. Br. J. Ophthalmol. 2002, 86, 1143-1147. [CrossRef] [PubMed]

64. Venkataraman, S.T.; Hudson, C.; Fisher, J.A.; Rodrigues, L.; Mardimae, A.; Flanagan, J.G. Retinal arteriolar and capillary vascular reactivity in response to isoxic hypercapnia. Exp. Eye Res. 2008, 87, 535-542. [CrossRef]

65. Roy, C.; Sherington, C. On the regulation of the blood supply of the brain. J. Physiol. 1890, 11, 85-108. [CrossRef]

66. Girouard, H.; Iadecola, C. Neurovascular coupling in the normal brain and in hypertension, stroke, and Alzheimer disease. J. Appl. Physiol. 2006, 100, 328-335. [CrossRef]

67. Attwell, D.; Buchan, A.M.; Charpak, S.; Lauritzen, M.; Macvicar, B.A.; Newman, E.A. Glial and neuronal control of brain blood flow. Nature 2010, 468, 232-243. [CrossRef]

68. Raichle, M.E.; Mintun, M.A. Brain work and brain imaging. Annu. Rev. Neurosci. 2006, 29, 449-476. [CrossRef] [PubMed] 
69. Tiret, P.; Chaigneau, E.; Lecoq, J.; Charpak, S. Two-photon imaging of capillary blood flow in olfactory bulb glomeruli. Methods Mol. Biol 2009, 489, 81-91. [CrossRef] [PubMed]

70. Cox, S.B.; Woolsey, T.A.; Rovainen, C.M. Localized dynamic changes in cortical blood flow with whisker stimulation corresponds to matched vascular and neuronal architecture of rat barrels. J. Cereb. Blood Flow Metab. 1993, 13, 899-913. [CrossRef] [PubMed]

71. Freygang, W.H., Jr.; Sokoloff, L. Quantitative measurement of regional circulation in the central nervous system by the use of radioactive inert gas. Adv. Biol. Med. Phys. 1958, 6, 263-279. [CrossRef] [PubMed]

72. Muoio, V.; Persson, P.B.; Sendeski, M.M. The neurovascular unit-concept review. Acta Physiol. (Oxf) 2014, 210, 790-798. [CrossRef] [PubMed]

73. Hendrikx, D.; Smits, A.; Lavanga, M.; De Wel, O.; Thewissen, L.; Jansen, K.; Caicedo, A.; Van Huffel, S.; Naulaers, G. Measurement of Neurovascular Coupling in Neonates. Front. Physiol. 2019, 10, 65. [CrossRef]

74. Howarth, C.; Sutherland, B.; Choi, H.B.; Martin, C.; Lind, B.L.; Khennouf, L.; LeDue, J.M.; Pakan, J.M.; Ko, R.W.; Ellis-Davies, G.; et al. A Critical Role for Astrocytes in Hypercapnic Vasodilation in Brain. J. Neurosci. 2017, 37, 2403-2414. [CrossRef] [PubMed]

75. Karagiannis, A.; Sylantyev, S.; Hadjihambi, A.; Hosford, P.S.; Kasparov, S.; Gourine, A.V. Hemichannel-mediated release of lactate. J. Cereb. Blood Flow Metab. 2016, 36, 1202-1211. [CrossRef] [PubMed]

76. Longden, T.A.; Dabertrand, F.; Koide, M.; Gonzales, A.L.; Tykocki, N.R.; Brayden, J.E.; Hill-Eubanks, D.; Nelson, M.T. Capillary K(+)-sensing initiates retrograde hyperpolarization to increase local cerebral blood flow. Nat. Neurosci. 2017, 20, 717-726. [CrossRef]

77. Iadecola, C. The Neurovascular Unit Coming of Age: A Journey through Neurovascular Coupling in Health and Disease. Neuron 2017, 96, 17-42. [CrossRef]

78. Hosford, P.S.; Gourine, A.V. What is the key mediator of the neurovascular coupling response? Neurosci. Biobehav. Rev. 2019, 96, 174-181. [CrossRef]

79. Riva, C.E.; Logean, E.; Falsini, B. Visually evoked hemodynamical response and assessment of neurovascular coupling in the optic nerve and retina. Prog. Retin. Eye Res. 2005, 24, 183-215. [CrossRef]

80. Metea, M.R.; Newman, E.A. Glial cells dilate and constrict blood vessels: A mechanism of neurovascular coupling. J. Neurosci. 2006, 26, 2862-2870. [CrossRef]

81. Mishra, A.; Newman, E.A. Inhibition of inducible nitric oxide synthase reverses the loss of functional hyperemia in diabetic retinopathy. Glia 2010, 58, 1996-2004. [CrossRef] [PubMed]

82. Donati, G.; Pournaras, C.J.; Munoz, J.L.; Poitry, S.; Poitry-Yamate, C.L.; Tsacopoulos, M. Nitric oxide controls arteriolar tone in the retina of the miniature pig. Invest. Ophthalmol. Vis. Sci. 1995, 36, 2228-2237. [PubMed]

83. Buerk, D.G.; Riva, C.E. Adenosine enhances functional activation of blood flow in cat optic nerve head during photic stimulation independently from nitric oxide. Microvasc Res. 2002, 64, 254-264. [CrossRef] [PubMed]

84. Dorner, G.T.; Garhofer, G.; Kiss, B.; Polska, E.; Polak, K.; Riva, C.E.; Schmetterer, L. Nitric oxide regulates retinal vascular tone in humans. Am. J. Physiol. Heart Circ. Physiol. 2003, 285, H631-H636. [CrossRef]

85. Mishra, A.; Newman, E.A. Aminoguanidine reverses the loss of functional hyperemia in a rat model of diabetic retinopathy. Front. Neuroenergetics 2011, 3, 10. [CrossRef]

86. Nakahara, T.; Mori, A.; Kurauchi, Y.; Sakamoto, K.; Ishii, K. Neurovascular interactions in the retina: Physiological and pathological roles. J. Pharmacol. Sci. 2013, 123, 79-84. [CrossRef]

87. Newman, E.A. Glial cell regulation of neuronal activity and blood flow in the retina by release of gliotransmitters. Philos Trans. R Soc. Lond B Biol. Sci. 2015, 370. [CrossRef]

88. Riva, C.E.; Harino, S.; Shonat, R.D.; Petrig, B.L. Flicker evoked increase in optic nerve head blood flow in anesthetized cats. Neurosci. Lett. 1991, 128, 291-296. [CrossRef]

89. Riva, C.E.; Logean, E.; Falsini, B. Temporal dynamics and magnitude of the blood flow response at the optic disk in normal subjects during functional retinal flicker-stimulation. Neurosci. Lett. 2004, 356, 75-78. [CrossRef]

90. Kotliar, K.E.; Vilser, W.; Nagel, E.; Lanzl, I.M. Retinal vessel reaction in response to chromatic flickering light. Graefes Arch. Clin. Exp. Ophthalmol. 2004, 242, 377-392. [CrossRef]

91. Nagel, E.; Vilser, W. Flicker observation light induces diameter response in retinal arterioles: A clinical methodological study. Br. J. Ophthalmol. 2004, 88, 54-56. [CrossRef] [PubMed] 
92. Formaz, F.; Riva, C.E.; Geiser, M. Diffuse luminance flicker increases retinal vessel diameter in humans. Curr Eye Res. 1997, 16, 1252-1257. [CrossRef] [PubMed]

93. Heitmar, R.; Summers, R.J. The Time Course of Changes in Retinal Vessel Diameter in Response to Differing Durations of Flicker Light Provocation. Invest. Ophthalmol. Vis. Sci. 2015, 56, 7581-7588. [CrossRef] [PubMed]

94. Polak, K.; Schmetterer, L.; Riva, C.E. Influence of flicker frequency on flicker induced changes of retinal vessel diameters. Invest. Ophthalmol. Vis. Sci. 2002, 43, 2721-2726.

95. Garhofer, G.; Resch, H.; Weigert, G.; Lung, S.; Simader, C.; Schmetterer, L. Short-term increase of intraocular pressure does not alter the response of retinal and optic nerve head blood flow to flicker stimulation. Invest. Ophthalmol. Vis. Sci. 2005, 46, 1721-1725. [CrossRef] [PubMed]

96. Garhofer, G.; Zawinka, C.; Huemer, K.H.; Schmetterer, L.; Dorner, G.T. Flicker light induced vasodilatation in the human retina-Effect of lactate and changes in mean arterial pressure. Invest. Ophthalmol Vis. Sci. 2003, 44, 5309-5314. [CrossRef]

97. Vo Van, T.; Riva, C.E. Variations of blood flow at optic nerve head induced by sinusoidal flicker stimulation in cats. J. Physiol. 1995, 482, 189-202. [CrossRef]

98. Buerk, D.G.; Riva, C.E.; Cranstoun, S.D. Frequency and luminance-dependent blood flow and K+ ion changes during flicker stimuli in cat optic nerve head. Invest. Ophthalmol Vis. Sci. 1995, 36, 2216-2227.

99. Falsini, B.; Riva, C.E.; Logean, E. Flicker-evoked changes in human optic nerve blood flow: Relationship with retinal neural activity. Invest. Ophthalmol. Vis. Sci. 2002, 43, 2309-2316.

100. Garhofer, G.; Zawinka, C.; Resch, H.; Huemer, K.H.; Dorner, G.T.; Schmetterer, L. Diffuse luminance flicker increases blood flow in major retinal arteries and veins. Vision Res. 2004, 44, 833-838. [CrossRef]

101. Aschinger, G.C.; Schmetterer, L.; Fondi, K.; Aranha Dos Santos, V.; Seidel, G.; Garhofer, G.; Werkmeister, R.M. Effect of Diffuse Luminance Flicker Light Stimulation on Total Retinal Blood Flow Assessed With Dual-Beam Bidirectional Doppler OCT. Invest. Ophthalmol. Vis. Sci. 2017, 58, 1167-1178. [CrossRef] [PubMed]

102. Garhofer, G.; Werkmeister, R.; Dragostinoff, N.; Schmetterer, L. Retinal blood flow in healthy young subjects. Invest. Ophthalmol. Vis. Sci. 2012, 53, 698-703. [CrossRef] [PubMed]

103. Fondi, K.; Bata, A.M.; Luft, N.; Witkowska, K.J.; Werkmeister, R.M.; Schmidl, D.; Bolz, M.; Schmetterer, L.; Garhofer, G. Evaluation of flicker induced hyperemia in the retina and optic nerve head measured by Laser Speckle Flowgraphy. PLoS ONE 2018, 13, e0207525. [CrossRef] [PubMed]

104. Hu, B.; Yan, L.F.; Sun, Q.; Yu, Y.; Zhang, J.; Dai, Y.J.; Yang, Y.; Hu, Y.C.; Nan, H.Y.; Zhang, X.; et al. Disturbed neurovascular coupling in type 2 diabetes mellitus patients: Evidence from a comprehensive fMRI analysis. Neuroimage Clin. 2019, 22, 101802. [CrossRef]

105. Yu, Y.; Yan, L.F.; Sun, Q.; Hu, B.; Zhang, J.; Yang, Y.; Dai, Y.J.; Cui, W.X.; Xiu, S.J.; Hu, Y.C.; et al. Neurovascular decoupling in type 2 diabetes mellitus without mild cognitive impairment: Potential biomarker for early cognitive impairment. NeuroImage 2019, 200, 644-658. [CrossRef]

106. Garhofer, G.; Zawinka, C.; Resch, H.; Kothy, P.; Schmetterer, L.; Dorner, G.T. Reduced response of retinal vessel diameters to flicker stimulation in patients with diabetes. Br. J. Ophthalmol. 2004, 88, 887-891. [CrossRef]

107. Lecleire-Collet, A.; Audo, I.; Aout, M.; Girmens, J.F.; Sofroni, R.; Erginay, A.; Le Gargasson, J.F.; Mohand-Said, S.; Meas, T.; Guillausseau, P.J.; et al. Evaluation of retinal function and flicker light-induced retinal vascular response in normotensive patients with diabetes without retinopathy. Invest. Ophthalmol. Vis. Sci. 2011, 52, 2861-2867. [CrossRef]

108. Lott, M.E.; Slocomb, J.E.; Shivkumar, V.; Smith, B.; Gabbay, R.A.; Quillen, D.; Gardner, T.W.; Bettermann, K. Comparison of retinal vasodilator and constrictor responses in type 2 diabetes. Acta Ophthalmol. 2012, 90, e434-e441. [CrossRef]

109. Bek, T.; Hajari, J.; Jeppesen, P. Interaction between flicker-induced vasodilatation and pressure autoregulation in early retinopathy of type 2 diabetes. Graefes Arch. Clin. Exp. Ophthalmol. 2008, 246, 763-769. [CrossRef]

110. Mandecka, A.; Dawczynski, J.; Blum, M.; Muller, N.; Kloos, C.; Wolf, G.; Vilser, W.; Hoyer, H.; Muller, U.A. Influence of flickering light on the retinal vessels in diabetic patients. Diabetes Care 2007, 30, 3048-3052. [CrossRef]

111. Dorner, G.T.; Garhofer, G.; Huemer, K.H.; Riva, C.E.; Wolzt, M.; Schmetterer, L. Hyperglycemia affects flicker-induced vasodilation in the retina of healthy subjects. Vision Res. 2003, 43, 1495-1500. [CrossRef] 
112. Kwan, C.C.; Lee, H.E.; Schwartz, G.; Fawzi, A.A. Acute Hyperglycemia Reverses Neurovascular Coupling During Dark to Light Adaptation in Healthy Subjects on Optical Coherence Tomography Angiography. Invest. Ophthalmol. Vis. Sci. 2020, 61, 38. [CrossRef] [PubMed]

113. Nagel, E.; Vilser, W.; Lanzl, I. Age, blood pressure, and vessel diameter as factors influencing the arterial retinal flicker response. Invest. Ophthalmol. Vis. Sci. 2004, 45, 1486-1492. [CrossRef] [PubMed]

114. Sharifizad, M.; Witkowska, K.J.; Aschinger, G.C.; Sapeta, S.; Rauch, A.; Schmidl, D.; Werkmeister, R.M.; Garhofer, G.; Schmetterer, L. Factors Determining Flicker-Induced Retinal Vasodilation in Healthy Subjects. Invest. Ophthalmol. Vis. Sci. 2016, 57, 3306-3312. [CrossRef]

115. Nguyen, T.T.; Kawasaki, R.; Wang, J.J.; Kreis, A.J.; Shaw, J.; Vilser, W.; Wong, T.Y. Flicker light-induced retinal vasodilation in diabetes and diabetic retinopathy. Diabetes Care 2009, 32, 2075-2080. [CrossRef]

116. Nguyen, T.T.; Kawasaki, R.; Kreis, A.J.; Wang, J.J.; Shaw, J.; Vilser, W.; Wong, T.Y. Correlation of light-flicker-induced retinal vasodilation and retinal vascular caliber measurements in diabetes. Invest. Ophthalmol. Vis. Sci. 2009, 50, 5609-5613. [CrossRef]

117. Skov Jensen, P.; Jeppesen, P.; Bek, T. Differential diameter responses in macular and peripheral retinal arterioles may contribute to the regional distribution of diabetic retinopathy lesions. Graefes Arch. Clin. Exp. Ophthalmol. 2011, 249, 407-412. [CrossRef]

118. Petersen, L.; Bek, T. The diameter response of retinal arterioles in diabetic maculopathy is reduced during hypoxia and is unaffected by the inhibition of cyclo-oxygenase and nitric oxide synthesis. Graefes Arch. Clin. Exp. Ophthalmol. 2016, 254, 2339-2346. [CrossRef]

119. Baier, J.M.; Funck, K.L.; Petersen, L.; Vernstrom, L.; Knudsen, S.T.; Bek, T.; Poulsen, P.L.; Laugesen, E. Retinal vessel reactivity is not attenuated in patients with type 2 diabetes compared with matched controls and is associated with peripheral endothelial function in controls. J. Diabetes Complicat. 2019, 33, 641-647. [CrossRef]

120. Blair, N.P.; Wanek, J.M.; Mori, M.; Shahidi, M. Abnormal retinal vascular oxygen tension response to light flicker in diabetic rats. Invest. Ophthalmol Vis. Sci 2009, 50, 5444-5448. [CrossRef]

121. Calver, A.; Collier, J.; Vallance, P. Inhibition and stimulation of nitric oxide synthesis in the human forearm arterial bed of patients with insulin-dependent diabetes. J. Clin. Invest. 1992, 90, 2548-2554. [CrossRef] [PubMed]

122. McVeigh, G.E.; Brennan, G.M.; Johnston, G.D.; McDermott, B.J.; McGrath, L.T.; Henry, W.R.; Andrews, J.W.; Hayes, J.R. Impaired endothelium-dependent and independent vasodilation in patients with type 2 (non-insulin-dependent) diabetes mellitus. Diabetologia 1992, 35, 771-776. [CrossRef] [PubMed]

123. Garhofer, G.; Resch, H.; Sacu, S.; Weigert, G.; Schmidl, D.; Lasta, M.; Schmetterer, L. Effect of regular smoking on flicker induced retinal vasodilatation in healthy subjects. Microvasc Res. 2011, 82, 351-355. [CrossRef]

124. Pemp, B.; Garhofer, G.; Weigert, G.; Karl, K.; Resch, H.; Wolzt, M.; Schmetterer, L. Reduced retinal vessel response to flicker stimulation but not to exogenous nitric oxide in type 1 diabetes. Invest. Ophthalmol. Vis. Sci. 2009, 50, 4029-4032. [CrossRef] [PubMed]

125. Pemp, B.; Weigert, G.; Karl, K.; Petzl, U.; Wolzt, M.; Schmetterer, L.; Garhofer, G. Correlation of flicker-induced and flow-mediated vasodilatation in patients with endothelial dysfunction and healthy volunteers. Diabetes Care 2009, 32, 1536-1541. [CrossRef]

126. Nguyen, T.T.; Cheung, N.; Wong, T.Y. Influence of Flickering Light on the Retinal Vessels in Diabetic Patients Response to Mandecka et al. Diabetes Care 2008, 31, e51. [CrossRef]

127. Barber, A.J. A new view of diabetic retinopathy: A neurodegenerative disease of the eye. Prog. Neuropsychopharmacol. Biol. Psychiatry 2003, 27, 283-290. [CrossRef]

128. Luu, C.D.; Szental, J.A.; Lee, S.Y.; Lavanya, R.; Wong, T.Y. Correlation between retinal oscillatory potentials and retinal vascular caliber in type 2 diabetes. Invest. Ophthalmol. Vis. Sci. 2010, 51, 482-486. [CrossRef]

129. Reichenbach, A.; Wurm, A.; Pannicke, T.; Iandiev, I.; Wiedemann, P.; Bringmann, A. Muller cells as players in retinal degeneration and edema. Graefes Arch. Clin. Exp. Ophthalmol. 2007, 245, 627-636. [CrossRef]

130. Lasta, M.; Pemp, B.; Schmidl, D.; Boltz, A.; Kaya, S.; Palkovits, S.; Werkmeister, R.; Howorka, K.; Popa-Cherecheanu, A.; Garhofer, G.; et al. Neurovascular dysfunction precedes neural dysfunction in the retina of patients with type 1 diabetes. Invest. Ophthalmol Vis. Sci 2013, 54, 842-847. [CrossRef]

131. Zaletel, M.; Strucl, M.; Pretnar-Oblak, J.; Zvan, B. Age-related changes in the relationship between visual evoked potentials and visually evoked cerebral blood flow velocity response. Funct. Neurol. 2005, 20, 115-120. [PubMed] 
132. Lipecz, A.; Csipo, T.; Tarantini, S.; Hand, R.A.; Ngo, B.N.; Conley, S.; Nemeth, G.; Tsorbatzoglou, A.; Courtney, D.L.; Yabluchanska, V.; et al. Age-related impairment of neurovascular coupling responses: A dynamic vessel analysis (DVA)-based approach to measure decreased flicker light stimulus-induced retinal arteriolar dilation in healthy older adults. Geroscience 2019, 41, 341-349. [CrossRef] [PubMed]

133. West, K.L.; Zuppichini, M.D.; Turner, M.P.; Sivakolundu, D.K.; Zhao, Y.; Abdelkarim, D.; Spence, J.S.; Rypma, B. BOLD hemodynamic response function changes significantly with healthy aging. NeuroImage 2019, 188, 198-207. [CrossRef] [PubMed]

134. Balbi, M.; Ghosh, M.; Longden, T.A.; Jativa Vega, M.; Gesierich, B.; Hellal, F.; Lourbopoulos, A.; Nelson, M.T.; Plesnila, N. Dysfunction of mouse cerebral arteries during early aging. J. Cereb Blood Flow Metab. 2015, 35, 1445-1453. [CrossRef]

135. Fabiani, M.; Gordon, B.A.; Maclin, E.L.; Pearson, M.A.; Brumback-Peltz, C.R.; Low, K.A.; McAuley, E.; Sutton, B.P.; Kramer, A.F.; Gratton, G. Neurovascular coupling in normal aging: A combined optical, ERP and fMRI study. NeuroImage 2014, 85, 592-607. [CrossRef] [PubMed]

136. Tarantini, S.; Hertelendy, P.; Tucsek, Z.; Valcarcel-Ares, M.N.; Smith, N.; Menyhart, A.; Farkas, E.; Hodges, E.L.; Towner, R.; Deak, F.; et al. Pharmacologically-induced neurovascular uncoupling is associated with cognitive impairment in mice. J. Cereb Blood Flow Metab. 2015, 35, 1871-1881. [CrossRef] [PubMed]

137. Tarantini, S.; Valcarcel-Ares, N.M.; Yabluchanskiy, A.; Fulop, G.A.; Hertelendy, P.; Gautam, T.; Farkas, E.; Perz, A.; Rabinovitch, P.S.; Sonntag, W.E.; et al. Treatment with the mitochondrial-targeted antioxidant peptide SS-31 rescues neurovascular coupling responses and cerebrovascular endothelial function and improves cognition in aged mice. Aging Cell 2018, 17. [CrossRef]

138. Garhofer, G.; Zawinka, C.; Resch, H.; Huemer, K.H.; Schmetterer, L.; Dorner, G.T. Response of retinal vessel diameters to flicker stimulation in patients with early open angle glaucoma. J. Glaucoma 2004, 13, 340-344. [CrossRef]

139. Gugleta, K.; Waldmann, N.; Polunina, A.; Kochkorov, A.; Katamay, R.; Flammer, J.; Orgul, S. Retinal neurovascular coupling in patients with glaucoma and ocular hypertension and its association with the level of glaucomatous damage. Graefes Arch. Clin. Exp. Ophthalmol. 2013, 251, 1577-1585. [CrossRef]

140. Gugleta, K.; Kochkorov, A.; Waldmann, N.; Polunina, A.; Katamay, R.; Flammer, J.; Orgul, S. Dynamics of retinal vessel response to flicker light in glaucoma patients and ocular hypertensives. Graefes Arch. Clin. Exp. Ophthalmol. 2012, 250, 589-594. [CrossRef]

141. Ramm, L.; Jentsch, S.; Peters, S.; Sauer, L.; Augsten, R.; Hammer, M. Dependence of diameters and oxygen saturation of retinal vessels on visual field damage and age in primary open-angle glaucoma. Acta Ophthalmol. 2016, 94, 276-281. [CrossRef] [PubMed]

142. Kotliar, K.; Hauser, C.; Ortner, M.; Muggenthaler, C.; Diehl-Schmid, J.; Angermann, S.; Hapfelmeier, A.; Schmaderer, C.; Grimmer, T. Altered neurovascular coupling as measured by optical imaging: A biomarker for Alzheimer's disease. Sci. Rep. 2017, 7, 12906. [CrossRef] [PubMed]

143. Szegedi, S.; Dal-Bianco, P.; Stogmann, E.; Traub-Weidinger, T.; Rainer, M.; Masching, A.; Schmidl, D.; Werkmeister, R.M.; Chua, J.; Schmetterer, L.; et al. Anatomical and functional changes in the retina in patients with Alzheimer's disease and mild cognitive impairment. Acta Ophthalmol. 2020. [CrossRef] [PubMed]

(C) 2020 by the authors. Licensee MDPI, Basel, Switzerland. This article is an open access article distributed under the terms and conditions of the Creative Commons Attribution (CC BY) license (http://creativecommons.org/licenses/by/4.0/). 